AT-TAJDID: Jurnal Pendidikan Dan Pemikiran Islam

(p-ISSN: 2548-5784 |e-ISSN: 2549-2101)

Vol. (5) (01), (Januari-Juni) (2021), (1-14)

Doi: http://dx.doi.org/10.24127/att.v5i01.1469

\title{
THE UNDERSTANDING OF ISLAMIC THOUGHT AS AN IDEOLOGY AND METHODOLOGY FOR THE INDONESIAN MILLENNIAL GENERATION
}

\author{
WA Ode Sifatu ${ }^{1}$ \\ Universitas Halu Oleo, Indonesia ${ }^{1}$ \\ sifatuwaode@gmail.com ${ }^{1}$ \\ Sardjana Orba Manullang ${ }^{2}$ \\ Universitas Krisnadwipayana $^{2}$ \\ somanullang@unkris.ac.id ${ }^{2}$ \\ Hasani Ahmad Said ${ }^{3}$ \\ UIN Syarif Hidayatullah Jakarta ${ }^{3}$ \\ hasaniahmadsaid@uinjkt.ac.id ${ }^{3}$ \\ Sunandar ${ }^{4}$ \\ UIN Syarif Hidayatullah Jakarta ${ }^{4}$ \\ Nandar62uin@gmail.com ${ }^{4}$ \\ Abdul Wahab Syakhrani ${ }^{5}$ \\ STAI Rasyidiyah Khalidiyah Amuntai ${ }^{5}$ \\ aws.kandangan@gmail.com ${ }^{5}$
}

\begin{abstract}
ABSTRAK
Kajian sosial keagamaan ini membahas pemahaman pemikiran Islam sebagai ideologi dan metodologi sebagai ilmu bagi generasi muda Muslim yang hidup, belajar, dan berkarya di era milenial. Banyak tudingan dan klaim bahwa Islam adalah agama yang hanya mengurusi urusan ideologi, ibadah agama serta mengesampingkan metodologi cara memahami islam intelektual sehingga Islam bermasalah untuk digambarkan dalam konteks era digital saat ini oleh generasi milenial di Indonesia sebagai negara yang merupakan rumah besar bagi pemeluk Muslim terbesar di dunia. Untuk menjawab permasalahan diatas, kami mencoba mengumpulkan literatur terkait. Kemudian kami menganalisanya dengan pendekatan fenomenologi di bawah design deskripsi kualitatif filsafat sebagai ilmu atau ilmu filosofis. Selanjutnya, data akan dievaluasi sistem koding pada teks, ditinjau koding, dan semua tema yang relevan. Akhirnya kami mendapatkan data yang kami yakini valid dan reliabel karena kami telah menjawab pertanyaan studi dengan metode studi review yang sesuai. Temuan bahwa Islam sebagai agama wahyu tentunya memiliki

Copyright (C) 2020, Universitas Muhammadiyah Metro| 1
\end{abstract}


ideologi sebagai agama yang bersahabat dengan seluruh umat manusia yang bertumpu pada kebenaran. Kebenaran yang dimiliki Islam ini dapat dipahami dan dipraktekkan dengan pendekatan metodologis berdasarkan kalam suci Alquran dan Hadist untuk dipahamkan pada generasi milenial.

Kata Kunci: Pemikiran Islam, Ideologi Agama, Metodologi Ilmiah, dan Generasi Milenial.

\begin{abstract}
This social study discussed the understanding of Islamic thought as a religious ideology and scientific methodology for the young Muslim generation who live, study, and work in a millennial time. There are many accusations and claims that Islam is a religion that only takes care of matters of religious ideology and worship and puts aside scientific and intellectual methodologies so that Islam is problematic to describe in the current context of the digital era by millennial generations in Indonesia as a country that is a big home for the world's largest Muslim adherents. To answer the above problems, we try to collect related literature. Then we study the phenomenological approach under the description of qualitative research design the work "Phenomenology in qualitative educational research: Philosophy as science or philosophical science." Next, the data will be checked and discussed, the original code created, the code reviewed, and all relevant themes reviewed. Finally, we get data findings that we believe are valid and reliable because we have answered the study questions with the appropriate method for review studies. The finding that Islam as a religion certainly has an ideology as a friendly religion to all human beings who rely on the truth. This truth, which Islam owned, can be understood and practiced with a methodological approach based on the holy Kalam Quran and Hadith.
\end{abstract}

Keywords: Islamic Thought, Religious Ideology, Scientific Methodologies, and Millennial Generation.

\section{A. INTRODUCTION}

Like other religions, Islam certainly has a unique ideology, especially concerning divinity and faith. (Dabashi, 2017; El-Zein, 1977; Aslan \& Putra, 2020; Aslan, Sihaloho, et al., 2020; Aslan, Suhari, et al., 2020). However, Islam emphasizes the issue of worship alone and obliges its Ummah to believe and practice other pillars such as the third Islamic law such as property and zakat and other matters that are not only understood as ideological but more scientifically capable be studied and rationalized through studies with methods and instruments of its correctness. Indeed, some Muslim ummah groups, especially the Ummah, do not understand what Islam is so that some people claim that ideology is human-made. Therefore, when Islam is said to be an ideology, it is not correct. This is because Islam comes from God Almighty, not from humans. This conclusion is obtained when one sees Islam from one side only, while the other is not seen. The first side is related to the faith, while the other is from the Shari'a side. It is possible to study and prove its truth in scientific methodology easily digested by every easy generation, especially those who live and learn in the modern era.

To refute such assumptions, Muslim scientists must respond by giving birth to arguments that can be proven through the findings of modern Islamic studies guided by easy-to-understand methodologies, not by mere theology and ideology, which are sometimes very subjective and personal to religion. For example, such accusations and 
assumptions may arise, because honestly, it is said that many young Indonesian Muslims are influenced by modern Western-style thinking and studies on secularism, which are sometimes inappropriate for the Muslim generation. Of course, every religious generation has a fortress to defend itself from views and thoughts irrelevant to Muslims, namely modern studies and thoughts full of efforts to banish the thoughts and beliefs of the Muslim generation of creeds. It must be admitted that it is like the mind of secularism, which is open only from the Western world, but it could be from anywhere in an increasingly globalized world. Such understanding is like secularism, which states that religion must be kept away from political life and worldly affairs.

On the other hand, religion is sufficient only in individual adherents, not to be applied in public, state, let alone universal issues. In the modern view of secularism, Islamic sharia includes rituals of worship such as prayer, fasting, zakat, hajj, umrah, charity, and other individual practices and family in nature so that the understanding of Islam is getting narrower and even more blurred from the Islamic Ummah, especially the Muslim generation who were born and lived in an era of all technology and globalization. Likewise, as the older Muslim generation, he hopes that the younger generation of Muslims must realize that Islam must have other thoughts that sometimes conflict with Islam itself. (Ramadan, 2009; Ramakrishna, 2009; Said, 2015; Qadir, 2014). Call it the word ideology attached to Islam as an ideology which is a word from a foreign language whose root word is 'idea' which comes from English, which means 'idea,' or 'thought.' The Greek verb Noida means 'to know,' to see with mind. The word "logic" comes from the Greek logos, which means "knowledge." When looking at the context of understanding Islam, the word 'ideology' did not initially exist in Islamic disciplines' literature and studies. Likewise, in Arabic, the word ideology is read as 'idiyuluji.' However, it does not mean that this word is later rejected or called something held, such as 'bid'ah' and other designations.

So, as Muslim researchers, we are interested in studying various sources of literature so that we can prove whether Islam is only an ideology or not. (Federspiel, 2001; Al-Attas Syed, 1993; Sumbulah, 2011; Rumadi, 2012). As a comparison, we also carry out other studies by reviewing literature that can prove that Islam can also teach its people through scientific methodology. In this way, perhaps we can compare Islam's nature as a methodology and the nature of Islam as an ideology itself. In the view of people in general, what is meant by ideology is a fundamental thought that will give birth to branch thoughts. It can be mentioned in a broad definition, a thought from which detailed derivative thoughts are built.

According to Berglund, (2010) to meet Islam as methodological teaching, we also find much literature that says Islam is a religion of the benefit of life for the universe. Islam turns out to be a religion that cares about improving the mind, worship methods, and social relations among the Ummah, including managing the relationship with the universe to live life in 
this world as provisions in the hereafter (Hammam, 2020). It is not like modern understanding, which only prioritizes life and the victory of worldly life. With the evidence of scientific literature study using the methodology, Islam is undoubtedly a religion like a light that always shines humanity both the beauty of the world and the hereafter (Siyono, 2021; Kiftiyah, K., Wahidah, W., \& Muslimah, M. (2021). Thus Islam will provide enlightenment and ease of life for the Ummah so that it is not surprising if Islam is always associated with glory and glory. That is, when viewed from its history, Islam has come with a variety of knowledge and gave birth to thousands of Muslim intellectuals. The developed knowledge makes it easier for humans to build world civilization even though their Ummah is not as rich as the early days of Islam.

About Islam as scientific resources throughout the centuries can be studied in past Islamic documents in the 6th to 14th centuries AD, Islam experienced its heyday. So it is surprising if, at that time, quite a several Muslim scholars have been known to be able to create great works from the holy Koran, which studies with scientific methodology until Islam is identical to science and technology to the world's flashlights (Fajrussalam, H., Ruswandi, U., \& Arifin, B. S. 2021; . Evidence of this evidence can be seen from the big names of Islamic philosophers and scientists named in many science and technology law names. The past glories are not beautiful if they can only be overcome but cannot be repeated. Just mention which non-Muslim writers actively mention names in Islamic technology civilization, such as Jabir bin Hayyan, al-Kindi, al-Khawarizmi, ar-Razi, al-Farabi, at-Tabari, al-Biruni, Ibn Sina, and Umar. Khayyam and a series of other names that were also very famous at that time. (Utomo, 2017).

\section{Islam as a methodological religion}

Islamic teachings about science and truth can be examined from three sides, namely science and truth, based on a philosophy where Islamic philosophy collects rules about ritual ways of worshiping the creator, and this must be studied and applied in a binding nature with rules and methods. (Chowdhury, 2018). The rules come higher than God, so humans as the implementers of these rules also have a firm and transparent legal basis and arguments. Islamic teachings believe that God's servant will get sanctions if he does not perform worship and orders do not comply with God's rules with these firm and transparent rules. Here every servant of the Islamic Ummah must make legal issues in Islam very objective; there should be no tendency and sometimes to recognize bargaining. This Islamic law has a procedure or method on every Saharan and practice.

In a scientific context or any matter the effort to complete the task in order to achieve the planned goals, humans are inevitably looking for ways or methods that can quickly get results, and these efforts do not miss hopes, circumstances, and needs that seek the truth of a problem and phenomenon in nature at large. Likewise, Islam's religion is no different from humans' natural knowledge when the study and language efforts also require specific 
methods to achieve demands. Main. The method of understanding in Islam, complete with laws and practices, is also the same as scientific efforts will determine the results according to the method used. (Chang et al., 2014).

Islam's efforts in teaching its Ummah to seek truth to find the truth and progress have been mentioned in our holy Koran. Islam ordered a check and recheck, and in a matter of religious content, it was called tabayyun. QS. Al-Hujurat verse 6, as written by Ulya, (2019), says:

O you who believe, if a wicked person comes to you with a message, then be careful to seek clarification so that you do not bring disaster to a people without knowledge that cause you to become a person. sorry people.

So religious orders in seeking or researching from uncomplicated reasoning to various research methods include human efforts to search for the truth about their God or a phenomenon. Before seeking the truth with our curiosity, we first look at the definition and nature of truth. Truth itself has a relative nature, which results in a truth that cannot last forever; in its time, new truth will emerge more from the previous truth.

\section{The methodological approach to understanding Islam}

The religion of Islam does not force its Ummah with doctrines and ideologies about the continuity of Islam. Instead, it takes the work of its people to accept Islam rationally. So through many ways and approaches contained in the study of science that is used to make it easier for humanity to accept Islam to modern drama today and in the future. As said by Karim et al., (2016) \& Munif (2020) that delivering Islamic studies and teaching diversity in Thai Islamic schools. Many Islamic studies methods are often conveyed through various approaches, including; 1) The normative methodology where Islam has always put forward normative values in Islamic teachings. Islamic and religious methodology offers three general methods or methodologies, namely the philosophy of Religion (Phenomenology), the study of religious adherents (Functionalism), and the study of all aspects of religious beliefs, ritual practices of worship, and life experiences of followers of certain religions (Lived religion). These three aspects exist in the search to understand what Islam. (Hutchinson et al., 2015).

These values and norms can be found by studying through the method of preaching or recitation with the help of the media as in modern times so that young people who are not participant students can understand every religious norm and value from both sources of the Koran and hadith through Islamic scholars or scholars. 2) The anthropological study method's approach where the effort in studying Islam is by finding out the development of religion in a society in a country or region. 3) Sociological methods and paradigms in which the Islamic Ummah can study religion by honing the individual's ability to adapt to the conditions and conditions of a social context, society, and civilization. 4) Theological practice method in which the Ummah can study and understand God's 
existence through the existence of the universe.

In this way, the human race will understand all the divine qualities that have been well described in worship to form a religious theology or belief in the existence of almighty power. 5) The phenomenological method in which religion is understood and practiced by examining various creation phenomena among various existing religions. 6) Philosophical methods, namely the study process with educational methods beginning with Islamic teachings, prove the truth of all God's creations. Based on rationality, the measure of truth is determined by proof of reason or evidencebased truth. 7) The study of historical methods in which the Ummah can study for understanding by familiarizing the study and reflection in order to gain knowledge by exploring and studying Islamic history and civilization with the method of studying stories and metaphors 8) The method of political study in which the human race can study religion by understanding Islamic values in state and community institutions, to gain a collective understanding and be integrated into the strength of society.

\section{B. METHOD}

This paper's primary purpose was to gain a deep understanding of Islamic thought as an ideology and methodology for young people born and live in the millennial era, which is often identified by the generation as easy to find something practical and dynamic. In answering this assumption, we chose a descriptive qualitative data answer design by examining the number of publications that discuss
Islamic thoughts both as an ideology and Islam as a religion that searches for the truth with a non-doctrinal methodology and doctrine in inviting its Ummah to become believers. The steps we are taking are conducting a preliminary reading of the relevant information. Next, we prepare and compile the data, and then we begin to review the literature relevant to the theme we discussed. Before we prepared the answers, we collected data and other materials to be reviewed as findings that answered Islamic studies' themes. Next, the initial coding activity and the coding results are proofreading, editing, and revising if the data we review is not relevant to the study's theme questions above. We will present this data as findings until we believe the data has validity and reliability as suggested by Bradshaw \& Stratford, (2010), Sgier, (2012) in their study of the approach to analyzing qualitative data. Social studies and education. Because this review relies on current data, we get all the data with the help of online data from online searches and Google scientists, Google Translate if we have difficulty understanding concepts in several foreign languages and are assisted by the Grammarly Premium writing editing application to display data and write more good.

\section{RESULTS AND DISCUSSION}

\section{Islamic thought as an ideology}

Ismail et al., (2020) studied the impact of preformist Islamic ideology on creating traditional madrasas as centers of sustainable Muslim community development in the Malaysian context. (Aslan, 2018). Madrassas have established Copyright (C) 2020, Universitas Muhammadiyah Metro| 6 
educational and religious centers that have served as places of outstanding Islamic education and a catalyst for community growth in Malaya's land since the early days of Islam. There are no modern architectural elements from the existing madrasah and contextual perspectives related to geographical factors such as the local sociocultural context. The semiotic theory with a structuralist system model, both madrasahs from direct observation and literature analysis, were studied. Factors such as position and placement, size and scale, facades and shapes, access and circulation, and hierarchy and spatial function are shown in the results.

Forkan, (2018) in his paper "Dynamics of Islamic Ideology Relating to Gender and Women's Education in South Asia," Her paper presents an investigation of women's education and women's rights in Islam in South Asia. Starting with the Moghul period and moving on to the colonial era and contemporary developments. The structure of gender roles in religious traditions is a consequence of various historical practices and ideological influences. Currently, there is substantial variability within and between religious communities concerning women's social status. The article tries to show that religious tradition in the South. Asians are not monolithic in their perceptions of gender-women's education and structure. Gender roles result from various historical practices that are ideological influence, writes Ravi Agrawal and concludes with more impartial gender relations.

Setiawan, (2020) in his research "Islamic Education in Southeast Asia." Islamic education in Southeast Asia reflects the diversity of Islam in that part of the world and certainly plays a central role in shaping and transmitting religious traditions. This study concludes that Southeast Asia has a vast and well developed Islamic structure. Education can be a vital resource in the ongoing war of Islam ideas, which is increasingly making the ideal Islamic way for the Asian region and the world as a Rahmatan Lil Alamin Islamic ideology.

Muzakki, (2007) in a paper entitled "Maintaining Islamic Ideology: Development of Islam in Indonesia after Indonesian Independence," this paper summarizes the development of Islamic journal publications in the country after independence; specifically paying attention to the symptoms that often occur among Islamic journal publishers and publishers, both in terms of thought and study results, and the role of Islamic printed news in the structure and learning of Islamic ideology. This will begin with a study of the development of Islamic news and printing and other publications. This study's essence is a description of the strength of Islamic publications with theology compared to nonprint efforts outside the realm of Islamic ideology. Solikhati, (2018) examines religious symbols in Islam and television ideology. Television has its way of expressing things based on its management policies. According to Fiske, (1987) it will be easier to see the ideology used by television by looking closely at how it uses certain symbols. Religious symbols shift more to cultural rather than normative meanings, as seen in religious television shows. The discussion in this paper focuses 
on the nuances of the meaning of religious symbols.

\section{Islam and methodology}

$\begin{array}{ccrr}\text { Saihu } & \& & \text { Aziz, } & \text { (2020) } \\ \text { implementation } & \text { of } & \text { pluralism } & \text { education }\end{array}$ methods in Islamic religious education subjects is right. (Aslan, 2019a). Their paper focuses on exploring the learning methods used in the learning of Islamic Religious Education in Jembrana-Bali. This shows that the Islamic learning process. Religious education with the pluralism method can shape the character of students. Both Hindus and Muslims are humanists, tolerant and inclusive, the newspaper said. The methods of contribution, enrichment, and social decision-making and action proposed by Allison Cumming-McCann can help foster understanding of diversity, the paper said. Using the peace education theory put forward by John Dewey (1859-1952).

Tambak, (2014) aims to determine the lecture method's concept and application in learning Islamic religious education. (Aslan, 2017; Aslan, 2017; Syamsuri et al., 2021; Liliana et al., 2021). This problem's study is carried out with a character approach rooted in Islamic teachings, namely the al-Qur'an and al-Hadith. The lecture method has six steps, all of which are integrated, applied in the learning process. Each method must have concrete steps that can be used in the learning process.

Ashaari et al., (2012) assessment of teaching and learning methodology in Islamic studies are vital. Islamic studies need to improve their methodology and approach to ensure its relevance and sustainable response to modernity demands.
Since the late 1970s, Islamic scholars have seriously discussed this failure and have suggested many actions to address the weakness. Their paper suggests various views of scholars on this issue and suggests ways to improve teaching and learning methods.

Shahi, (2019) applied Sufism to foreign relations' philosophy: an initial inquiry into the paths of epistemology, ontology, and methodology. The article said that a nonWestern worldview could not make foreign affairs less Eurocentric or more "global," He asks whether "Sufism" will provide fertile ground for developing a non-derivative and non-exclusive Global Foreign Relations philosophy. The article concludes that Sufism upholds a "threefold attribute" as a proven doctrine with a broad spatialtemporal global spread, which gives it the particular fundamental position of formulating an anon-Eurocentric theory of global international relations, the authors add. To make its case, it uses observations gleaned from the poetry of a Sufi scholar in the 13th century, Jalāl ad-Dāmān Muhammad Rūmāni. The author concludes that Sufiism allows for the formulation of such a theory with "a unique basic status."

Two requirements for theoretical appraisal in Islamic economics are clarified by Furqani \& Haneef, (2012) namely internal honesty (doctrinal integrity, conceptual integrity, and empirical integrity) and relational consistency (doctrine and functional existence, ideals/goals and factual knowledge, beliefs, and evidence, a priori and a posteriori normative and positive dimensions). Khan, (2017) noted that Islamic economics's methodology is studied, 
from Islamic teachings to Islamic economics. There can be overwhelming, vague, or misleading literature on Islamic economic methodology. The translation of Islamic economics into social science does not improve. In a contemporary context, we must consider primary sources and propose theories based on that interpretation. With some examples, this paper outlines the suggested technique.

\section{DISCUSSION}

\section{Essential of Islamic ideology understanding}

This section will discuss the results of a study to understand Islamic ideology and methodology for Muslims' generation in the millennial era in Indonesia. Of the many publications we have reviewed, we can explain that the essential publication implies that Islam is identified with the understanding of Islamic teachings, namely a set of ideologies that state that Islam is universal and has become the foundation for all aspects of life from religion, economy, public relations, socio-politics. And aspects of the world and the hereafter. For example, the Islamic understanding of women's gender equality in Islam in various South Asia countries. In their view of women's caste, education, and structure, Asians are not monolithic. Gender stereotypes stem from several historical traditions that were ideologically influential, writes Ravi Agrawal, and end with calls for more objective gender relations. Regarding gender and equality discussed (Pearse \& Connell, 2016) about gender norms and socioeconomic justice.
Setiawan, (2020) for example, regarding Islamic education in Southeast Asia, which has become a model for Islamic teachings in many other countries, will undoubtedly give a new color to Southeast Asia. A similar study will become a model and center in shaping imagination and image for the world community who want to see Islam's color with an ideology that is different from the color of Islam in other regions or countries. So Setiawan has concluded that Islam in Southeast Asia has a different structure, style, and color and is well developed. For example, a similar study comes from Hayat, (2012) which contributes to Islam's development in Islam's future advancement in Southeast Asia. (Aslan, Hifza, et al., 2020; Suhardi et al., 2020; Aslan \& Hifza, 2019; Aslan \& Suhari, 2019; Hifza \& Aslan, 2019; Aslan, 2019). According to Hayat, Southeast Asia's Islam is comparatively more moderate than the Middle East's Islam. By trading routes and not through military invasion, Islam entered Southeast Asia. As a result of the relatively peaceful Islamization process, Islam is among the very least welcoming Islam. In Southeast Asia, Islam only spread towards the end of the 17 th century. Islam's resurgence has altered the face of political Islam.

\section{Islam and methodology in modern days}

Allah as the only God for Muslims certainly sends as an end-time religion with a concept of understanding and a method of seeking understanding readily accepted by common sense. For example, our findings in the study of Saihu \& Aziz, (2020) raise how the application of teaching methods for aspects of pluralism in Islamic religious 
schools emphasizes the effort to explore appropriate methodology and is used in Islam in Jembrana-Bali so that Islam is readily accepted even though they are inside Islamic minority areas. With a clear concept, Islam can become a religion that also respects modernism, which is an effort to respond if Islam's ideology to the influence of westernization is misunderstood. Through an easily described method, Islam seeks to convince the world of Islamic beliefs with modern values. Such as democracy, civil rights, rationality, equality, and progress, all of which can be understood through conceptual and methodological studies.

The findings of Islamic studies that emphasize methodology in recognizing Islamic teachings were conveyed by Shahi, (2019) through Sufism's science in establishing relationships between countries of different religions. He also said that many studies provide a way of understanding through various science lines, such as epistemology, ontology, and other research. At the end of his paper, he said that beyond Islam, social attitudes do not make international affairs less eurocentric or more "global," questioning if "Sufism" would offer fertile ground for creating a Global Foreign Relations non-derivative and nonexclusive ideology. In terms of relations with the world outside Islam in modern times, Islam has a holy book relevant to the present era. As a large religion, with several adherents of nearly two billion and growing, Islam will continue to develop itself utilizing da'wah work, a distribution and communication method with nations outside Islam, by promoting scientific and dialectic approaches. This is what Furqani \& Haneef,
(2012) study, internal

authenticity (doctrinal credibility, logical integrity, and scientific integrity) and coherence of relationships (doctrine and practical life, ideals/goals and objective knowledge, opinions and proof, moral and constructive aspects a priori and a posteriori).

Regarding methodology in understanding Islamic law, Sunnis agree that ijma, a method of the agreement by scientists, is the third source of Islamic law after the Qur'an and the Sunnah of the Prophet. This is the Islamic way of determining the rules or methods of settling a case, not from both sources. (Vogel, 2000). It is also necessary to determine the form of the concept and method of 'ijma' in modern times to solve the common problems faced by Muslims in the millennial era, which sometimes have no other solution. Likewise, the concepts and methodology in understanding Islam itself. When understood in words, Islam means' obeying the will of the creator.

While its adherents are called 'Muslims,' which means a group of people who submit to obey a monotheistic god or only acknowledge one worship, he is the God who exclaims all the worlds, mentioned in the unifying language of Islam in Arabic as the title 'Allah.'

Meanwhile, the understanding of 'Islam' is that of those who are devout and loyal to Allah. All understanding, Islam provides guidance or methodology, the way humans research and find out from before they did not know.

The Islamic generation's attitude in the millennial era, Islam does not limit its Ummah to continue to use the methodology 
to understand Islam. So that they understand and can separate which life is good in Islam and which life is wrong according to the guidance of Islamic methodology. a similar study is evidenced by Al Farabi, (2020) who notes that in the millennial era, Islamic education is an effort to create an accomplished generation. The new millennial era is a period of life devoted to the millennial generation born and the rapid development of technology and the internet. On the one hand, technical progress made fact-finding and understanding easier for students, but on the other hand, it created a change in beliefs and approaches to religious life and practice.

\section{CONCLUSION}

Understanding the ideology of religion is very important. It is the same as an ideology that becomes a religious ideology. Someone embraces that having a sense of faith and piety can be embedded in the Islamic Ummah, especially those of the Islamic generation born and who lived in a global era. Suppose the teachings of the Islamic religion that have been presented in the holy book and the hadith of the Prophet can be understood and become true identity and ideology. In that case, the generation of Islam as the generation that will continue Islam will survive the global currents and millennial era.

All of the findings that we summarize in the results and discussion section clearly emphasize the understanding of Islamic ideology, it is evident that Islam is not just a religion of Gaudiya affairs with God. However, Islam is a religion that has a clear ideology and separates what is right and vanity. Likewise, to understand Islamic ideology correctly, Islam teaches its people to know Islam, utilizing again knowledge or methodology, not just believing in dogma and doctrine. The conclusion is clear that Islam is a religion that puts forward a methodology in regulating and teaching its people to be fair and faithful followers. With a firm ideology, the generation of Muslims who live in the millennial era can balance mingle with other religious communities.

\section{E. REFERENCES}

Al Farabi, M. (2020). Islamic Education In The Millennial Era: Efforts To Realize The Excellent Generation. Proceeding International Seminar of Islamic Studies, 1(1), 875-890.

Al-Attas Syed, M. N. (1993). Islam and Secularism. Hindustan Publications.

Ashaari, M. F., Ismail, Z., Puteh, A., Samsudin, M. A., Ismail, M., Kawangit, R., Zainal, H., Nasir, B. M., \& Ramzi, M. I. (2012). An assessment of teaching and learning methodology in Islamic studies. Procedia-Social and Behavioral Sciences, 59, 618-626.

Aslan. (2017). Strategi Pembelajaran Dalam "Go Sport" Kurikulum Pendidikan Karakter. Madinah: Jurnal Studi Islam, 4(1), 10-19-10-19.

Aslan. (2017). Makna Pendidikan Karakter Dalam Strategi Pembelajaran Di Setiap Sendi-Sendi Pendidikan. Madinah: Jurnal Studi Islam, 4(2), 111-119-111-119.

Aslan. (2018). Dinamika Pendidikan Islam di Zaman Penjajahan Belanda. SYAMIL: Jurnal Pendidikan Agama Islam (Journal of Islamic Education), 6(1), 39-50. https://doi.org/10.21093/sy.v6i1.102 4 
Aslan. (2019). Peran Pola Asuh Orangtua di Era Digital. Jurnal Studia Insania, 7(1), 20-34. http://dx.doi.org/10.18592/jsi.v7i1.2 269

Aslan. (2019). SEJARAH PERJALANAN KURIKULUM PENDIDIKAN ISLAM DI MALAYSIA. TaLimuna: Jurnal Pendidikan Islam, 8(1), 2945.

http://dx.doi.org/10.32478/talimuna. v1i1.238

Aslan \& Hifza. (2019). Kurikulum Pendidikan Masa Penjajahan Jepang Di Sambas. Edukasia Islamika, 4(2), 171-188.

https://doi.org/10.28918/jei.v4i2.229 5

Aslan, Hifza, \& Suhardi, M. (2020). DINAMIKA PENDIDIKAN ISLAM DI THAILAND PADA ABAD 1920. Nazhruna: Jurnal Pendidikan Islam, 3(1), 38-54. https://doi.org/10.31538/nzh.v3i1.47 6

Aslan, \& Putra, P. (2020). Dampak Islamisasi terhadap Agama dan Kebudayaan Lokal di Paloh, Kalimantan Barat, dalam Buku "Agama \& Budaya Nusantara Pasca Islamisasi (Vol. 1). eLSA Press.

Aslan, Sihaloho, N. T. P., Nugraha, I. H., Karyanto, B., \& Zakaria, Z. (2020). Paradigma Baru Tradisi "Antar Ajung" Pada Masyarakat Paloh, Kabupaten Sambas. IBDA': Jurnal Kajian Islam Dan Budaya, 18(1), 87-103. https://doi.org/10.24090/ibda.v18i1.3 354

Aslan \& Suhari. (2019). Sejarah Kurikulum Pendidikan Islam di Brunei Darussalam. Jurnal Iqra': Kajian Ilmu Pendidikan, 4(1), 113-127. https://doi.org/10.25217/ji.v4i1.448
Aslan, Suhari, Antoni, Mauludin, M. A., \& Mr, G. N. K. (2020). Dinamika Keagamaan Masyarakat Perbatasan Paloh Kabupaten Sambas, Kalimantan Barat. Jurnal Antropologi: Isu-Isu Sosial Budaya, 22(1), 90-101. https://doi.org/10.25077/jantro.v22.n 1.p90-101.2020

Berglund, J. (2010). Teaching Islam. Waxmann Verlag.

Bradshaw, M. B., \& Stratford, E. (2010). Qualitative research design and rigour.

Chang, D. Y., Benantar, M., Chang, J. Y., \& Venkataramappa, V. (2014). Authentication and authorization methods for cloud computing security. Google Patents.

Chowdhury, M. (2018). Emphasizing morals, values, ethics, and character education in science education and science teaching. MOJES: Malaysian Online Journal of Educational Sciences, 4(2), 1-16.

Dabashi, H. (2017). Theology of Discontent: The Ideological Foundation of the Islamic Revolution in Iran. Routledge.

El-Zein, A. H. (1977). Beyond ideology and theology: The search for the anthropology of Islam. Annual Review of Anthropology, 6(1), 227254.

Fajrussalam, H., Ruswandi, U., \& Arifin, B. S. (2021). Spotlight and Criticism of Islamic Religious Education in Schools. Bulletin of Science Education, 1(1), 91-96.

Federspiel, H. M. (2001). Islam and Ideology in the Emerging Indonesian State: The Persatuan Islam (Persis), 1923 to 1957. BRILL.

Fiske, J. (1987). Television Culture. Routledge. 
Forkan, A. L. I. (2018). The Dynamics of Islamic Ideology with Regard to Gender and Women's Education in South Asia. Asian Studies, 6(1), 3352.

Furqani, H., \& Haneef, M. A. (2012). Theory appraisal in Islamic economic methodology: Purposes and criteria. Humanomics.

Hayat, B. (2012). Kontribusi Islam Terhadap Masa Depan Peradaban Di Asia Tenggara. MIQOT: Jurnal Ilmu-Ilmu Keislaman, 36(1).

Hammam, H. (2020). Penanaman Akidah Melalui Pembiasaan Membaca Kitab Ta'limul Mubtadi'in Aqoid Ad-Diin di SD Negeri Kabupaten Tegal. Attractive: Innovative Education Journal, 2(1), 49-60.

Hifza \& Aslan. (2019). Problematika Pendidikan Islam Melayu Patani Thailand. Al-Ulum, 19(2), 387-401. https://doi.org/10.30603/au.v19i2.86 4

Hutchinson, A. J., O'Leary, P., Squire, J., \& Hope, K. (2015). Child protection in Islamic contexts: Identifying cultural and religious appropriate mechanisms and processes using a roundtable methodology. Child Abuse Review, 24(6), 395-408.

Ismail, A. S., Taufik, F. A., \& Aziz, N. S. A. (2020). The Influence of Preformist Islamic Ideology on Traditional Madrasa Design as a Sustainable Communal Development Centre in Malaysian Context. Journal of Environmental Treatment Techniques, 8(1), 47-60.

Karim, P., Asyari, S. M., \& Mahnun, N. (2016). Delivering Islamic studies and teaching diversity in Southern Thai Islamic schools. $A$ LJ $\bar{a} M i$ 'ah: Journal of Islamic Studies, 54(1), 123-147.
Khan, M. (2017). Methodology of Islamic economics: From Islamic teachings to Islamic economics. TUJISE, 5(1), 2018.

Kiftiyah, K., Wahidah, W., \& Muslimah, M. (2021). The Theories of Makki and Madani According to Classical and Contemporary Scholars. Bulletin of Pedagogical Research, 1(1), 147-155

Liliana, L., Putra, P., \& Aslan, A. (2021). The strategy of tadzkirah in implementing characters at man insan cendekia sambas. edukasi: Jurnal Pendidikan Islam, 9(1), 1-17.

Munif, M. R. (2020). Ranah Afektif Perspektif Al-Ghazali (Kajian Terhadap Kitab Kimia Sa'adah). Attractive: Innovative Education Journal, 2(1), 143-152.

Muzakki, A. (2007). Cultivating Islamic ideology: Print Islam in postindependence Indonesia (a preliminary study). Studia Islamika, 14(3).

Pearse, R., \& Connell, R. (2016). Gender norms and the economy: Insights from social research. Feminist Economics, 22(1), 30-53.

Qadir, Z. (2014). Radikalisme Agama di Indonesia: Pertautan Ideologi Politik Kontemporer dan Kekuasaan. Pustaka Pelajar.

Ramadan, T. (2009). Radical Reform: Islamic Ethics and Liberation. Oxford University Press.

Ramakrishna, K. (2009). Radical Pathways: Understanding Muslim Radicalization in Indonesia. Greenwood Publishing Group.

Rumadi. (2012). Islam dan otoritas keagamaan. Walisongo: Jurnal Penelitian Sosial Keagamaan, 20(1), 25-54. https://doi.org/10.21580/ws.20.1.183

Said, H. A. (2015). Radikalisme agama dalam perspektif hukum islam. al'adalah, 12(1), 593-610. 
https://doi.org/10.24042/adalah.v12i 1.238

Saihu, M. M., \& Aziz, A. (2020). Implementasi Metode Pendidikan Pluralisme Dalam Mata Pelajaran Pendidikan Agama Islam. Belajea; Jurnal Pendidikan Islam, 5(1), 131150.

Setiawan, A. R. (2020). Islamic Education in Southeast Asia.

Sgier, L. (2012). Qualitative data analysis. An Initiat. Gebert Ruf Stift, 19, 1921.

Shahi, D. (2019). Introducing Sufism to International Relations Theory: A Preliminary inquiry into epistemological, ontological, and methodological pathways. European Journal of International Relations, 25(1), 250-275.

Solikhati, S. (2018). Simbol Keagamaan Dalam Islam dan Ideologi Televisi. Islamic Communication Journal, 2(2), 121-146.

Suhardi, M., Mulyono, S., Aslan, Syakhrani, H. A. W., \& Putra, P. (2020). Perubahan kurikulum lembaga pendidikan Islam di Sambas pada masa Kesultanan Sambas. Ta'dibuna: Jurnal Pendidikan Islam, 9(1), $\quad$ 034-048. https://doi.org/10.32832/tadibuna.v9i 1.2715

Sumbulah, U. (2011). Islam dan Ahl AlKitab: Kajian Living Sunnah di Kalangan Pimpinan NU, Muhammadiyah dan Hizbut Tahrir Malang. Al-Tahrir, 11(1), 151-171.

Syamsuri, S., Kaspullah, K., \& Aslan, A. (2021). The understanding strategy of worship to exceptional children. edukasi: Jurnal Pendidikan Islam, 9(1), 18-31.

Siyono, S. (2021). Multicultural Education at Pesantren (The Study of API ASRI Islamic Boarding School at
Tegalrejo Magelang). Bulletin of Science Education, 1(1), 83-90.

Tambak, S. (2014). Metode Ceramah: Konsep dan Aplikasi dalam Pembelajaran Pendidikan Agama Islam. Jurnal Tarbiyah, 21(2).

Ulya, R. (2019). Telaah QS. Al Hujurat: 13 perspektif Badiuzzaman Said Nursi [PhD Thesis]. UIN Sunan Ampel Surabaya.

Utomo, G. (2017). IndonesIan IslamIc cIvIllzatIon In Internet era: A multiperspective review. Addin, 11(1), 157-180.

Vogel, F. E. (2000). Islamic law and the legal system of Saudi: Studies of Saudi Arabia (Vol. 8). Brill. 